\title{
IMMUNE THROMBOCYTOPENIC PURPURA (ITP) IN HEPATITIS B-VIRUS INFECTION- A CASE REPORT
}

\author{
UDDIN MK ${ }^{1}$, UDDIN MM ${ }^{2}$, GIAS UDDIN KA ${ }^{1}$, SARDAR MH ${ }^{3}$, HOSSAIN MZ ${ }^{3}$, ISLAM MS ${ }^{4}$, \\ SAFIULLAH SM ${ }^{5}$, RAHMAN MJ ${ }^{6}$
}

\begin{abstract}
A 30 years old male presented with fever, headache, myalgia, anorexia, petechial haemorrhage, easy bruising, gum bleeding and purpuric rash. Initially it appeared to be a case of autoimmune thrombocytopenic purpura (ITP) but finally our patient was diagnosed as a case of immune thrombocytopenia due to hepatitis B-virus infection. In this report we document the immune thrombocytopenic purpura (ITP) in a 30 years old male patient which is due to hepatitis B-virus infection in the replicative phase. Assessment of the replicative status and activity of liver disease of the patient was done.
\end{abstract}

Key words: Immune Thrombocytopenic Purpura (ITP), Hepatitis B-Virus Infection.

J Dhaka Med. Coll. 2010; 19(1) : 72-73.

\section{Introduction:}

ITP is an autoimmune condition in which pathogenic antibodies binds platelets, resulting in accelerated platelet clearance. The disorder is primary and idiopathic in most adult patients although it can be associated with connective tissue disease (such as lupus), lymphoproliferative disease (such as lymphoma), medication and infection (HCV \& HIV), target anti-platelet anti-bodies include glycoprotein Ib / IIIa and Ib /IX on the platelet membrane although anti-bodies are found in only two third of patients. The mechanism underlying druginduced thrombocytopenia are thought in most cases to be immune, although exception exist (such as chemotherapy). HIV and hepatitis Cvirus are associated with thrombocytopenia that has immune mediated mechanism and these cases respond to immunoemodulation. Additional mechanism are direct suppression of platelet production (HIV) and cirrhosis related splenomegaly (HCV). ${ }^{1,2}$

\section{Case Report:}

A 30 years old male patient admitted in Medicine Unit 1 in 200 Bedded Hospital, Narayanganj on 02-02-10 with the complaints of fever, myalgia, anorexia, petechial haemorrhage, easy bruising, occatioal gum bleeding and purpuric rash. There was no history of jaundice and high colour urine. He had abdominal discomfort with anorexia and itching throughout the body. He was anxious looking with average body built, pulse $80 / \mathrm{m}$, blood pressure $130 / 80 \mathrm{mmHg}$, no lymphadinopathy, temperature $100^{\circ} \mathrm{F}$ continued in nature, purpur rash in the lower extremities. Some are red, some are black which did not blench on pressure. Systemic examination including respiratory, cardiovascular and endocrine systems also did not reveal any abnormality.

Investigations revealed-Hb $12.5 \mathrm{gm} / \mathrm{dl}$, ESR 40 $\mathrm{mm} 1^{\text {st }}$ hour, and Tc of WBC $5000 / \mathrm{cmm} \mathrm{DC}$ of WBC-Neutrophil-68\%, Lymphocyte-25\%, Monocyte-02\%, Eosinophil-05\%. Platelet count $<35,000$ /cumm. Peripheral blood film (PBF) shows thrombocytopenia. Bone marrow examination reveals increased number of megakaryocytes with variable size \& shape, serum bilirubin-1.6g/d1, ALT 50 IU, Urea-30 $\mathrm{mg} / \mathrm{dl}$, creatinine-1.1gm/dl, BT-prolonged, CTnormal, PT-prolonged, APTT-normal. Patient was initially diagnosed as ITP, then he was

1. Consultant, 200 Bedded Hospital, Narayanganj.

2. Professor of Microbiology, Northen International Medical Collage, Dhaka.

3. Assistant Professor, Department of Medicine, Dhaka Medical College, Dhaka

4. Registrar (Medicine), 200 bedded Hospital, Narayanganj.

5. Medical Officer, Sir Salimullah Medical College Hospital, Dhaka.

6. Professor and Chairman, Department of Haematology, Bangabandhu Sheikh Mujib Medical University, Dhaka.

Correspondence: Dr. Md. Kazim Uddin 
treated with steroid $1 \mathrm{mg} / \mathrm{dl}$ body wt. and other supportive therapy for 4 weeks but patient did not improve. Then patient was again reevaluate by further investigations of viral markers, HIV-1 \& 2-negative, Anti HCVnegative, HBsAg-positive, HBeAg-positive, HBvDNA-positive, albumin globulin ratio altered. Considering all the history, clinical findings\& laboratory investigations including, virological markers, finally the patient was diagnosed as a case of auto immune thrombocytopenia purpura (ITP) due to hepatitis B-virus infection.

\section{Discussion:}

The occurrence of immune thrombocytopenic purpura (ITP) due to hepatitis B-virus infection is very rare. We suggest that immune thrombocytopenic purpura (ITP) has to be kept in mind in differential diagnosis of hepatitis B-virus infection in any patient presented with history thrombocytopenia in developing country. Thrombocytopenia associated with hepatitis B-virus infection lead to an amelioration in the platelet count. Most cases are refectory thrombocytopenia which may be treated with infusion of IVG or Anti-D and interferon-a. Treatment with corticosteroid is not recommended in HBV infection. , $^{4,6}$ Patient was treated by antiviral agent lamivudine. Patient symptomatically improved.His liver function improved after 6 month. Serum ALT level decreased and Albumin level increased. A depovir dipivoxyl- a nucleoside analogues, has recently become available in Bangladesh. This drug is shown to be benefit in chronic HBV patients in the replicative phage and has shown very low rates of resistance after one year of therapy. $7,8,9$ This may be an alternate to lamivudine. Therapy and its efficacy in patients with decompensated cirrhosis due to chronic HBV needs to be investigated.

\section{References:}

1. Fogarty PF et al. The epidemiology of immune thrombocytopenia purpura. Carr opin Hematol 2007 Sep: 14 (5): 515-9.

2. Goerge J.N. et. al. Idiopathic thrombocytopenic purpura, a practice guide line developed by exploit method for the American society of Haematology Blood. 1996; 88: 3-40.

3. Goerge JN.Drug induced thrombocytopenia purpura, a systemic review of published case reports, Am Intern Medicine. 1998; 129: 886-90.

4. Cokins PW, New Card AC. Treatment modalities blood disorders. Semin, Hematol. 1992; 27: 6474.

5. Blan Chette V, 1mbach I. Andrew M. Clal. Randomized trail of intravenous immunoglobulin G. intravenous Anti-D and oral predmisolone in childhood acute auto immune thrombocytopenia purpura. Lancet. 1994; 344: 703-7.

6. Lichin A. The ITP practice guideline: what, why and for whom? Blood 1996; 88: 1-2.

7. Liaw YF. Leung NWY, Chang TT. Guan R, Tai D1, Neg KY, et al. Effect of extended lamivudine therapy in asian patients with chronic hepatitisB. Gastroenterology. 2000; 119: 172-80.

8. Marulin P, Chang TT, lim GG, et al. AdepovirDipivoxil for the treatment of hepatitis-B antigen positive chronic hepatitis-B. N Engl. J Med. 2003; 348: 808-16.

9. Hadziyannis SJ. Nicolag CT. Heathcole EJ, et al. Adepovir-dipivoxil for the treatment of hepatitis$\mathrm{B}$ with e antigen-negative chronic hepatitis-B. N Engl J Med. 2003; 348: 800-77. 